BARBRA STREISAND 


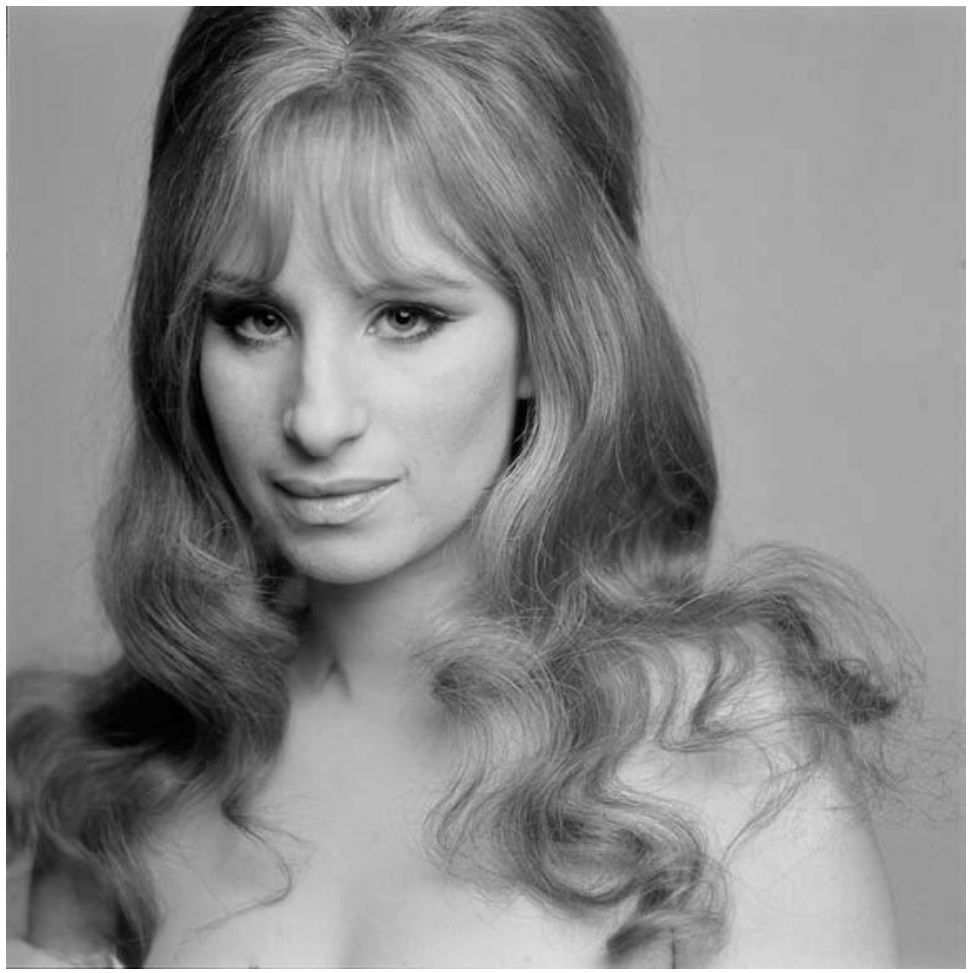




\section{Barbra Streisand}

Redefining Beauty, Femininity, and Power

NEAL GABLER

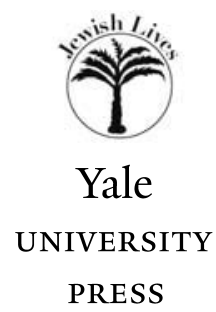

New Haven and London 


\section{Copyright () 2016 by Neal Gabler.}

All rights reserved.

This book may not be reproduced, in whole or in part, including illustrations, in any form (beyond that copying permitted by Sections 107 and Io8 of the US Copyright Law and except by reviewers for the public press), without written permission from the publishers.

Yale University Press books may be purchased in quantity for educational, business, or promotional use. For information, please e-mail sales.press@yale.edu (US office) or sales@yaleup.co.uk (UK office).

Set in Janson type by Integrated Publishing Solutions, Grand Rapids, Michigan. Printed in the United States of America.

frontispiece: Photo by Lawrence Schiller. (C) Polaris Communications, Inc., All Rights Reserved.

Library of Congress Control Number: 2015957531

ISBN 978-0-300-2109I-0

A catalogue record for this book is available from the British Library.

This paper meets the requirements of ANSI/NISO Z39.48-I992

(Permanence of Paper).

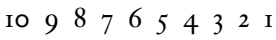


For my beloved daughters, Laurel and Tänne, and my beloved son-in-law, Braden, And for all those who have ever been told they could not succeed 
You never quit, do you?

-Hubbell Gardner, The Way We Were 